\title{
KONSTRUKTIVIZAM U PEDAGOGIJI: KARAKTERISTIKE, DOMETI I OGRANIČENJA ${ }^{1}$
}

\author{
Marina Ćirićé, Dragana Jovanović \\ Univerzitet u Nišu, Filozofski fakultet u Nišu, Departman za pedagogiju
}

\begin{abstract}
Apstrakt: U radu su razmatrana osnovna polazišta konstruktivističke paradigme u pedagogiji i društveno-humanističkim naukama. Analizom relevantne literature, autorke su ukazale na teoretičare koji su shvatanjima da ljudi oblikuju realnost u skladu sa svojim potrebama, interesovanjima, predrasudama i kulturnim tradicijama doprineli utemeljenju konstruktivizma. Takođe, istakle su najznačajnije savremene pravce razvoja, predstavnike radikalnog, socijalnog i razvojnog konstruktivizma i karakter njihovog odnosa prema načinu prezentovanja i perspektivi tumačenja stvarnosti, znanja i učenja.

S obzirom da se prvenstveno vezuje za postmodernistička shvatanja, konstruktivizam je sagledan sa aspekta „nove paradigme”, alternative tradicionalnim pozitivističkim shvatanjima. U skladu sa izraženom relativističkom pozicijom, umnogome različitom od tradicionalne paradigme, analiziran je epistemološko-metodološki značaj konstruktivističke paradigme za istraživanja u pedagogiji. Perspektiva razvoja prikazana je komparacijom dominantnih shvatanja sa aspekta kritike i doprinosa konstruktivizma u oblasti vaspitanja i obrazovanja.
\end{abstract}

Ključne reči: konstruktivizam, paradigma, pedagogija, epistemologija, istraživanja

\section{Uvod}

Razvoj pedagogije i drugih društvenih nauka umnogome zavisi od osnovnih polazišta, orijentacija, vizija i pristupa. Vrhunska generalizacija naučnog viđenja sveta i idejna srž naučnog establišmenta, kako je nazivaju Berberović i Šošić (2006), u literaturi je definisana različitim terminima: centralni koncept nauke (Bronowski, 1965), naučni stil mišljenja (Vedenov \& Sačkov, 1970), tip mišljenja (Born, 1967), (glavna) paradigma (Kuhn, 1962), istraživačke tradicije (Laudan, 1977) i naučni istraživački programi (Lakatos, 1978) (prema: Berberović i Šošić, 2006: 94). Vre-

\footnotetext{
${ }^{1}$ Napomena: Rad je nastao tokom nagažovanja na projektu 179002: Indikatori i modeli usklađivanja porodičnih i poslovnih uloga, koji finansira Ministarstvo prosvete, nauke i tehnološkog razvoja Republike Srbije.

${ }^{2}$ marina.ciric@filfak.ni.ac.rs
} 
menom se u literaturi izdvojio i postao opšteprihvaćen termin paradigma, čije se poreklo vezuje za Tomasa Kuna (Kuhn, 1962) i od koga potiču dva osnovna značenja: 1) u širem smislu, kao konstelacija uverenja, vrednosti, tehničkih procedura jedne naučne zajednice, i 2) u užem značenju, konkretna rešenja u okviru tih konstelacija, koja mogu služiti kao primeri i modeli za obogaćivanje postojećih naučnih znanja (Kun, 1974: 11). Kun je kasnije, u skladu sa osnovnim značenjima, pored termina paradigma koristio izraz disciplinarna matrica, disciplinarna jer okuplja naučnike u okviru određene discipline a matrica jer se sastoji od uređenih elemenata koji zahtevaju pojedinačnu specifikaciju (Orman, 2016).

Termin paradigma široko je prihvaćen i korišćen od strane različitih autora kao sistem verovanja, pogled na svet ili okvir za istraživanja i razvoj teorije (Willis, 2007), opšti naučni pristup u koji je ugrađen određeni opšti filozofski i pojmovni okvir (Mužić, 1999) ili matrica za naučnu disciplinu (Filstead, 1979). Kun (1974) je smatrao da je paradigma zavisna od dostignuća društvene zajednice u određenom periodu, kao i od same naučne zajednice. U literaturi se često ističe uticaj društvenoidejnog konteksta, te se paradigma dovodi u vezu sa misaonim stilom (Brdar, 2009) i označava kao kulturni artefakt (Husen, 1988, prema: Savićević, 1996). Pretežno konstruktivistički orijentisani autori naglašavaju značaj paradigme kao inicijalne ideje, polazišta koje nije jasno omeđeno i pruža samo početnu osnovu istraživačima u određenoj naučnoj disciplini. Guba i Linkolnova (Guba \& Lincoln, 1994) paradigmu shvataju kao osnovni skup verovanja koja usmeravaju akciju, ali koja nikada ne mogu da budu uspostavljena kao konačno istinita. Gergen i Gergenova (Gergen i Gergen, 2006) ističu da paradigme predstavljaju motore stvaranja smisla i okvir za rešavanje problema zajednice. Takođe, $u$ literaturi se naglašava da, osim usaglašenosti uverenja, paradigma uključuje pristupe i procedure u istraživanjima (Ristić, 2016; Savićević, 1996; Wahyuni, 2012).

Uočljivo je da navedena shvatanja sugerišu na odnos paradigme i naučne zajednice, da je paradigma socijalno konstruisana, determinisana naučnom zajednicom, tačnije preovlađujućim shvatanjima u zajednici, ali i određuje naučnu zajednicu kao model koji se koristi i prema kojem se istraživači upravljaju u svom radu. Dakle, karakteriše je aktivna uloga u podsticanju smislene organizacije daljih istraživačkih aktivnosti. Kako navode Laketa i Vasilijević (2006: 44), paradigma u pedagogiji predstavlja „...posebnu metodološku logiku - poseban obrazac, put kojim se istražuju pedagoške pojave, odnosi se na definisanje naučnoistraživačkog problema, organizaciju istraživanja, sistematizaciju i kategorizaciju naučnih rezultata, kao i na formulaciju naučnih pojmova, teorija i zakona...". Samim tim, paradigma utiče na ostvarivanje kontinuiteta naučnog znanja. Uopšteno govoreći, paradigma prožima sve aspekte procesa istraživanja, određuje koji će problemi biti istraživani i na koji način (Denzin \& Lincoln, 2000).

Savremeni pristup društvenim naukama karakteriše pluralizam paradigmi kojima se podstiče razvijanje strategija istraživanja i implicira različitost u koncipiranju istraživačkih rešenja (Ponterotto, 2005; Johnson \& Onwuegbuzie, 2004). Premda u nauci postoji više različitih istraživačkih pogleda, paradigmatskih pristupa naučnom istraživanju (pozitivistički, postpozitivistički, interpretativistički, konstruktivistički, 
pristup kritičkih teorija, participatorni, pragmatistički, transformativni i dr.), Guba i Linkolnova (Guba \& Lincoln, 1994) naglašavaju da istraživač ne može započeti istraživanje ukoliko ne odredi jasno kojom paradigmom je vođen njegov pristup. Spomenuti autori ističu da se proučavanje paradigmi zasniva na tri osnovna, međusobno povezana pitanja, odnosno polazišta: 1) ontološko polazište koje pruža odgovor na pitanje: Koji je oblik i priroda realnosti, i samim tim, šta je to što može da se spozna o toj realnosti?; 2) epistemološko polazište koje se tiče prirode relacija između onog koga zna ili onoga koji će znati i onoga što se može spoznati a uslovljeno je ontološkom spoznajom realnosti i 3) metodološko polazište kojim se teži otkrivanju načina kojim se može doći do spoznaje u nauci. Kada je reč o međusobnom odnosu među navedenim polazištima, pojedini autori (Taylor \& Medina, 2013; Scotland, 2012; Wahyuni, 2012) objašnjavaju da vrednost ontoloških i epistemoloških polazišta nije u njihovom apsolutnom dokazivanju već u pružanju određene osnove i perspektive gledanja na predmet proučavanja i podsticanju istraživačkog pristupa saznavanju. Na osnovu polazišta istraživačkih paradigmi koju su priredili autori Guba i Linkolnova (Guba \& Lincoln, 1994) obuhvaćena su pozitivistička, postpozitivistička, kritička i konstruktivistička paradigma. U kasnijim radovima navedenih autora, nastalih pod uticajem Herona i Risona (Heron \& Reason, 1997) pojavljuje se paradigma participativnih istraživanja i ukazuje se na značaj aksiološke, vrednosno zasnovane paradigme (Lincoln \& Guba, 2005) (Tabela 1).

Tabela 1. Inovirana osnovna polazišta alternativnih istraživačkih paradigmi (Lincoln \& Guba, 2005: 168)

\begin{tabular}{|c|c|c|c|c|c|}
\hline & Pocitíñam & Postpocitivizcon & Kr'iticka tearija & Konstruktivican & Pcoticipativna \\
\hline $\begin{array}{l}\text { Ontologija } \\
\text { Koji je oblik i } \\
\text { priroda } \\
\text { realnosti, i } \\
\text { samim tim, šta } \\
\text { je to što može } \\
\text { da se spozna o } \\
\text { toj realnosti? }\end{array}$ & $\begin{array}{l}\text { naivmi realizam } \\
-" \text { "prava" } \\
\text { stvarnost, ona } \\
\text { kojuje moguće } \\
\text { shvatiti }\end{array}$ & $\begin{array}{l}\text { kriticai } \\
\text { realizam - } \\
\text { "prava" } \\
\text { stvarnost, ali } \\
\text { ona kojuje } \\
\text { moguće samo } \\
\text { nesavršeno i } \\
\text { relativistički } \\
\text { shvatiti }\end{array}$ & $\begin{array}{l}\text { istorij ski } \\
\text { realizam - } \\
\text { virtuelna } \\
\text { stvarnost koju } \\
\text { oblikuju } \\
\text { socijalne, } \\
\text { političke, } \\
\text { kulturne, } \\
\text { ekonom ske, } \\
\text { etričke i polne } \\
\text { vrednosti; } \\
\text { kristališe se } \\
\text { vremenom }\end{array}$ & $\begin{array}{l}\text { relativizam - } \\
\text { lokalne i } \\
\text { specific čno } \\
\text { konstruisane } \\
\text { stvarnosti }\end{array}$ & $\begin{array}{l}\text { participativni } \\
\text { realizam; } \\
\text { subjektivno- } \\
\text { objektivna } \\
\text { stvarnost } \\
\text { obogaćena } \\
\text { umom i } \\
\text { datim kosmosom }\end{array}$ \\
\hline $\begin{array}{l}\text { Epistemologija } \\
\text { Koja je priroda } \\
\text { odnosa izm eđu } \\
\text { onog koji } \\
\text { zna ili onoga } \\
\text { koji će znati i } \\
\text { onoga što se } \\
\text { može spoznati? }\end{array}$ & $\begin{array}{l}\text { dualisticka/ } \\
\text { objektivistička } \\
\text { nalazi suistiniti }\end{array}$ & $\begin{array}{l}\text { modifikovana } \\
\text { dualistička/ } \\
\text { objektivistička; } \\
\text { kriticka } \\
\text { tradicija } \\
\text { /zajednica; } \\
\text { nalazi } \\
\text { verovatno } \\
\text { istiniti }\end{array}$ & $\begin{array}{l}\text { transakciona/ } \\
\text { subjektivistička } \\
\text { nalazi do kojih } \\
\text { se dolazi preko } \\
\text { vrednosti }\end{array}$ & $\begin{array}{l}\text { transakciona/ } \\
\text { subj ekti vstička; } \\
\text { stvoreni nal azi }\end{array}$ & $\begin{array}{l}\text { kriticka/ } \\
\text { subjektivistička; } \\
\text { uparticipativnoj } \\
\text { transakciji sa } \\
\text { kosmosom; } \\
\text { prošrena } \\
\text { epistemologija } \\
\text { iskustvenog, } \\
\text { propozicionogi } \\
\text { praktičnog } \\
\text { znanja; } \\
\text { ko-kreirani } \\
\text { nalazi }\end{array}$ \\
\hline $\begin{array}{l}\text { Kako može } \\
\text { istraži vač (onaj } \\
\text { koji će znati) da } \\
\text { sazna bilo šta, } \\
\text { koji se model } \\
\text { prim enjuje u } \\
\text { samom } \\
\text { istraživačkom } \\
\text { procesu? }\end{array}$ & $\begin{array}{l}\text { eksperimentalna } \\
\text { manipulativna; } \\
\text { verifikacija } \\
\text { hipoteza; } \\
\text { pretežno } \\
\text { kvantitativne } \\
\text { metode }\end{array}$ & $\begin{array}{l}\text { modifikovana } \\
\text { eksperimentalna/ } \\
\text { manipulativna; } \\
\text { opovrgavanje } \\
\text { hipoteza; može } \\
\text { uključivati } \\
\text { kvalitativne } \\
\text { metode }\end{array}$ & $\begin{array}{l}\text { dijal oška/ } \\
\text { dijal ektička }\end{array}$ & $\begin{array}{l}\text { hermeneutička/ } \\
\text { dijalektička }\end{array}$ & $\begin{array}{l}\text { politička } \\
\text { participacija u } \\
\text { kol aborati vnim } \\
\text { akcionim } \\
\text { istraživanjima; } \\
\text { upotreba jezika } \\
\text { zasnovanog na } \\
\text { zajednickom } \\
\text { iskustvenom } \\
\text { kontekstu }\end{array}$ \\
\hline
\end{tabular}


Svaka od navedenih paradigmi neosporno pruža adekvatnu osnovu za proučavanje problema u pedagogiji. Ukazivanjem na razlike u polazištima navedenih paradigmi, može se uvideti da, s jedne strane, pozitivizam i postpotzitivizam, a s druge, kritičke teorije konstruktivizam i participativizam imaju suštinski različita utemeljenja u ontologiji, metodologiji i epismemologiji, te se u literaturi često nailazi na oprečne stavove kada je u pitanju njihova kompatibilnost (Niglas, 1999). Guba i Linkolnova (Guba \& Lincoln, 1994) smatraju da se metode mogu primeniti kao kompatibilne, ali je teško da autori koji zastupaju pozitivističku mogu zastupati i konstruktivističku paradigmu. Važno je naglasiti da se o alternativnim paradigmama govori iz perspektive odnosa sa pozitivizmom kao, još uvek, konvencionalnom paradigmom. Alternativne paradigme još uvek su u različitim fazama konstituisanja i kritičkog odnosa prema njihovim definicijama, značenjima, implikacijama (Gojkov, 2007; Guba \& Lincoln, 1994; 2005; Ristić, 2016; Stojnov, 2005).

\section{Osnovna polazišta konstruktivističke paradigme}

Konstruktivička paradigma obuhvata heterogen skup teorijskih pristupa, prisutan u mnogim naučnim disciplinama. Njen razvoj u društvenim i humanističkim naukama ogleda se u načinu prezentovanja i perspektivi tumačenja stvarnosti, znanja i učenja. Okosnicu konstruktivizma čine shvatanja da ljudi oblikuju realnost u skladu sa svojim potrebama, interesovanjima, predrasudama i kulturnim tradicijama (Gergen i Gergen, 2006; Ševkušić, 2011). Konstruktivizam kao teorija stvarnosti, znanja i učenja ne predstavlja potpuno novu i originalnu paradigmu u nauci jer se njeni začeci mogu naći u delima autora XVIII, XIX i s početka XX veka. Prema Topolovčaninu i saradnicima (2017), konstruktivistička pozicija i njen razvoj u nauci može se sagledati iz tri teorijske perspektive: 1) filozofske (ontološke i epistemološke); 2) psihološke teorije učenja i 3) didaktičke teorije nastave.

Stojnov (2005), Ševkušić (2011), Ristić (2016) Milutinović (2016) i Jukić (2013) ukazuju na najznačajnije autore u filozofiji, psihologiji i didaktici i njihov doprinos utemeljenju osnovnih polazišta konstruktivističke paradigme. Navedeni autori naglašavaju da se koreni konstruktivističkih shvatanja mogu naći u filozofijama koje su se odvojile od racionalističkih i objektivističkih tendencija društva. Najistaknutiji filozof, čija su gledišta uticala na utemeljenje konstruktivističke metateorije bio je Đanbatista Viko, ukazujući da ljudi neprestano transformišu sebe i svet oko sebe i ističući ulogu kulture kao paukove mreže značenja u koju je čovek upleten, zbog čega je smatrao da nauka mora tragati za značenjima (Stojnov, 2005; Ševkušić, 2011). Takođe, filozofske ideje Imanuela Kanta značajno su uticale na dalje oblikovanje i razvoj konstruktivističke teorije u pedagogiji i drugim drušvenim naukama (Jukić, 2013).

U oblasti psihologije, teorija Žana Pijažea, tvorca ,genetičke epistemologije” (Pijaže, 1983; 1994; 1996) smatra se jednom od ranih vrsta konstruktivizma, na čijem temelju su nastali evolucionarni, radikalni, socijalni konstruktivizam. Prema Pijažeu, proces intelektualnog i kognitivnog razvoja podseća na biološki čin koji 
zahteva prilagođavanje zahtevima sredine (Lutz \& Huitt, 2004; Yilmaz, 2011). Pijaže konstruktivizam posmatra kao neminovnost u razvoju nauke, stvaralački proces koji objašnjava na sledeći način: „konstrukcija novih struktura izgleda da je odlika jednog opšteg, suštinski stvaralačkog procesa, koji se ne svodi na metod usvajanja: od neuspeha uzročnog redukcionizma na polju nauka o stvarnom, do neuspeha logičkog redukcionizma, kada je reč o granicama formalizacije i o odnosima razvijenijih struktura sa logičkim strukturama, svuda smo svedoci rušenja ideala o potpunoj dedukciji koja bi podrazumevala preformaciju i to u korist jednog sve očigledijeg konstruktivizma" (Pijaže, 1983: 88).

Ruski psiholog Lav Semjonovič Vigotski uticao je na razvoj socijalnog konstruktivizma preispitivanjem čovekove prirode i ,unutrašnjeg” života i ukazivanjem da ljudi u svom unutrašnjem funkcionisanju ispoljavaju suštinski ista etička kao i retorička razmatranja kakva razmenjuju u spoljnom svetu (Blake \& Pope, 2008; Jukić, 2013; Stojnov, 2005). Posebno je isticao značaj simetrične komunikacije koja je shvaćena kao osnov za doživljaj sopstvene individualnosti i razumevanja drugih osoba (Roth \& Radford, 2010). U skladu sa tim, Vigotski (1977: 135) je naglašavao da je ,...stvaranje pojmova uvek produktivno, a ne reproduktivno...".

Doprinos Džeroma Brunera (1960) konstruktivizmu ogleda se u shvatanju učenja kao procesa stvaranja značenja. Informacije same po sebi nisu dovoljne, već one moraju biti strukturirane tako da pojedinac može da efikasnije proširi i produbi znanje (Takaya, 2008).

$\mathrm{U}$ svom radu o istorijskom kontekstu konstruktivizma u pedagogiji Milutinović (2016) ističe pedagoške ideje Žan Žaka Rusoa, Johana Hajniha Pestalocija i Fridriha Frebela bliske savremenim konstruktivističkim stanovištima. Dok je Ruso izražavao potrebu za negovanjem učeničke slobode, individualizovanje nastave i samoregulacije učenika, dotle je Pestaloci verovao da nastava treba da se ostvaruje kroz aktivno angažovanje učenika sa stvarima i pojavama u svetu i da počiva na dijalogu između nastavnika i učenika, a Frebel je naglašavao samoaktivnost. Značajan doprinos konstruktivizmu u pedagogiji doneo je reformski pokret progresivnog obrazovanja i Džon Djui kao njegov najznačajniji predstavnik. Djui (1966) je smatrao da znanje nikada nije reprezentacija stvarnosti i da je veza između znanja i realnosti rezultat individualnih i socijalnih iskustava. Najpoznatiji konstruktivistički koncept tokom prve polovine XX veka u Evropi zasnovan je na idejama Marije Montesori (Montessori, 1912, prema: Ültanır, 2012), koja je zastupala stav o podeli autoriteta između nastavnika i učenika tako da učenici mogu da se angažuju i kritički odnose prema obrazovanju koje stiču. Među savremenim pedagozima se ističe Paulo Freire (Freire, 2005) koji je i ukazivao da se znanje stiče putem razmene ideja i konstruisanjem značenja, odnosno smisla.

Iako se nagoveštaji konstruktivističkih ideja mogu naći u shvatanjima teoretičara u različitim periodima, izvesno je da je ovo relativno nov fenomen o kojem se prevashodno govori u kontekstu postmoderne. Vilson (Wilson, 1997) smatra da, iako se navedeni pojmovi često koriste kao sinonimi, postmodernizam shvata kao filozofiju a konstruktivizam kao generalnu teoriju kognicije. On navodi da se koreni konstruktivizma čvrsto nalaze u postmodernoj filozofiji kao kontekstualnoj kon- 
strukciji značenja. U skladu sa tim Vilson (Wilson, 1997: 10) je sumirao karakteristike konstruktivizma: 1) znanje se shvata kao dinamičko; 2) značenje je konstruisano; 3) učenje je prirodna posledica izvodjenja; 4) apstrakcija je kritična za izvodjenje stručnjaka i za postajanje stručnjakom; 5) podučavanje je pregovaranje sa konstrukcijom značenja; 6) mišljenje i percepcija su nerazdvojivi; 7) rešavanje problema je centralno za kogniciju; 8) percepcija i razumevanje su takodje centralni za kogniciju. Uopšteno, postmorednizam i konstruktivizam odlikuje činjenica da pojedinci kreiraju ili konstruišu sopstveno razumevanje ili znanje kroz interakciju onoga u šta veruju i ideja, događaja i aktivnosti sa kojima dolaze u kontakt (Blake \& Pope, 2008). Ovde je naglasak na kontekstu i relativnoj prirodi stvarnosti jer se priroda stvari ne otkriva već izumljuje u međusobnim odnosima.

Konstruktivistička paradigma u okviru osnovnih polazišta vremenom razvija različite pristupe. Zasnovan na teoriji Pijažea $(1983$; 1994; 1996) nastao je razvojni konstruktivizam. U literaturi se najčešće pominje radikalni konstruktivizam čiji predstavnici odbacuju mogućnost postojanja objektivne ontološke stvarnosti i insistiraju na shvatanju realnosti kao konstrukcije (Maturana \& Varela, 1992; von Glasersfeld, 1995). Kod socijalnog konstrukcionizma, nasuprot radikalnom konstruktivizmu, fokus nije na aktivnosti, već na kolektivnom generisanju značenja putem jezika i socijalnih procesa (Schwandt, 1997). Proces razumevanja ogleda se u saradnji, odnosno da ,...dok razgovaramo međusobno, dok slušamo i nečiji tuđi glas, dokle god postavljamo pitanja i razmatramo alternativne metafore, dokle god se igramo na ivici razumnog, mi prelazimo prag kojim ulazimo u jedan novi svet značenja. Naša zajednička budućnost je u stvaranju“ (Gergen i Gergen, 2006: 12).

\section{Specifičnosti konstruktivizma u odnosu na pozitivističku paradigmu}

Konstruktivistički pogled na svet vremenom se uobličio u uticajnu i rasprostranjenu paradigmu postmoderne koja predstavlja istaknutu alternativu pozitivističkim shvatanjima. Iako nije ostvaren potpuni konsenzus među autorima oko paradigme koju zastupaju, pojavom konstruktivističkih ideja dovedene su u pitanje mnoge tradicionalne pretpostavke vezane za znanje i naučno istraživanje (Gojkov, 2006; Gergen i Gergen, 2006). U društvenim naukama, a time i pedagogiji, konstruktivizam je jedna od paradigmi koje su epistemološko-metodološka alternativa pozitivizmu, a koje se često nazivaju „nova paradigma” (Anderson \& Herr, 1999).

Shvatanjem da „...stvarnost nije ono što izgleda da jeste...“, konstruktivizam označava alternativnu paradigmu čija se otcepljujuća pretpostavka zasniva na ontološkom relativizmu (Guba \& Lincoln, 1994: 110). Pozitivistička paradigma je svoje polazište pronašla u poimanju sveta kao objektivne eksterne realnosti i ,...da je osnovni karakter pozitivne filozofije da posmatra sve fenomene kao potčinjene nepromenljivim prirodnim zakonima..." (Kont, 1989: 28). Nasuprot stavu da naučno znanje egzistira nezavisno od lične percepcije, nepromenjivo i statično predstavlja oličenje univerzalne istine, konstruktivisti odbacuju mogućnost postojanja pozitivne 
ontologije u smislu izvora znanja što predstavlja svojevrsni zaokret u pravcu refleksivnosti u pristupu razumevanja i objašnjavanja sveta (Babić, 2007).

Kada je reč o osnovnim načelima konstruktivističke metateorije, Stojnov (2005) izdvaja i pojašnjava suštinska polazišta, „tačke oslonca“ na kojima se konstruktivizam zasniva a koje su suprotstavljene načelima tradicionalne, odnosno pozitivističke paradigme.

○ Relativizam nasuprot realizmu. Realizam se zasniva na traganju za istinom, dok se realativističko mišljenje zasniva na skepticizmu i permisivnosti, čime se ukazuje da postoji neograničen broj tački gledišta, neuskladivih opisa i teorija o tome kako svet izgleda.

- Relacionizam nasuprot esencijalizmu. Iz esencijalističke perspektive, prave naučne teorije nastoje da opišu suštinsku prirodu stvari, i takvim teorijama nisu potrebna dalja objašnjenja. U relacionizmu se saznavanje gradi i proizvodi u odnosima.

- Participativizam nasuprot objektivizmu. Za razliku od objektivističkog poimanja znanja i istine kojim se nastoji da ukloni proizvoljnost i subjektivnost i koje je u tesnoj vezi sa teorijama opravdanja (oslanjanja na autoritet činjenica), participativizam označava epistemološku doktrinu kojom se ukazuje da ljudi ne mogu izdvojiti sebe iz slike koju posmatraju. Ono što ljudi mogu da saznaju o svetu uvek je ograničeno njihovim načinom postojanja i strategijama saznavanja.

- Potencijalizam nasuprot aktualizmu. Dosadašnja traganja za čovekovom prirodom oslanjala su se na strategiju aktualizma kojom se isticala ne samo aktivna priroda čoveka nego i saznajna strategija da je znanje o čovekovoj prirodi datost koja je može utvrditi. Konstruktivisti zastupaju potencijalizam u smislu proučavanja dinamičkih interakcija i procesa koji se neprestano odvijaju i sačinjavaju čoveka (Stojnov, 2005: 103-186).

Suština konstruktivističkog gledišta je u tome da znanje nije određeno onim što ljudi saznaju, odnosno spoljašnjom objektivnom stvarnosti, nije pasivno primljeno kroz čula ili putem komunikacije već predstavlja tvorevinu aktivnog saznavaoca. Ljudi svetu pristupaju posredstvom mnoštva modela koje razvijaju i biraju putem saznanja, odnosno odbacuju ih ili potkrepljuju (Ristić, 2016). Stvarnost je konstruisana u umovima ljudi te se ne može smatrati spoljašnjim i nezavisnim entitetom (Hansen, 2004, prema: Ševkušić, 2011).

Nasuprot epistemološkoj objektivnosti, konstruktivizam podrazumeva širu transakciono-subjektivističku zasnovanost, gde se znanje vidi kao stvoreno u interakciji između istraživača i ispitanika. Karakteristike pozitivističkog pristupa istraživanjima ogledaju se prevashodno u izbegavanju subjektivnosti u smislu korišćenja standardizovanih mernih instrumenata, ali i situacije između istraživača i ispitanika, koja se ogleda u vrednosnoj neutralnosti $i$ distanci. Podrazumeva se da je znanje merljivo i primenljivo $u$ istraživanjima jer objekti, događaji, ljudi ne menjaju svoje karakteristike i mogu se prikazati univerzalno, u šablonima. Iz navedenih karakteristika proizilaze osnovni kriterijumi pozitivizma: 1) kriterijum istinitosti naučnog 
znanja, koji se ostvaruje kroz empirijske dokaze i 2) kriterijum objektivnosti koji se ispoljava u distanciranju istraživača od predmeta istraživanja. Na ovaj način ostvaruje se ,pozitivno“ naučno saznanje, zasnovano na objektivno datim činjenicama i strogim zakonima (Potkonjak, 1977; Savićević, 1996).

Kod konstruktivističkog pristupa dolazi do napuštanja tradicionalnog shvatanja a kriterijumi za utvrđivanje prihvatljivosti znanja posmatraju se kao epistemičke vrednosti (interna konzistentnost, ekološka valjanost, narativna ubedljivost, društveni konsenzus). Znanje shvaćeno na ovaj način posmatra se kao lokalni proizvod kulture, veštačka tvorevina uma, a njegova svrha je da omogući sprovođenje i isprobavanje održivosti raznovrsnih društvenih praksi (Ševkušić, 2006). Konstruktivizam $\mathrm{u}$ istraživanja uvodi značaj agensnosti, altruizma i proaktivnosti. Smatra se da, osim čula i razuma, razumevanje procesa ljudskog delovanja zahteva i imaginaciju. Podaci o svetu se u um ne unose putem čula već se proizvode, kao načini viđenja stvarnosti. Ono što se smatra očiglednim (na primer, čovek, žena, istina, biće) zapravo su proizvodi komplikovanih diskurzivnih praksi (Gojkov, 2007). Smatra se da jezik ima formativnu ulogu, odnosno da nije trasparentan sistem za komunikaciju već sistem koji je konstruisan u odnosu na društvenu stvarnost (Stojnov, 2005).

Takođe, nema jednoobraznog shvatanja metodologije, već postoji pluralizam referentnih okvira jer je pretpostavka da ljudi žive u brojnim isprepletanim, paralelnim realnostima, te je znanje proizvod kulture i atefakt uma (Scotland, 2012). Prema metodološkim pretpostavkama pozitivistička paradigma je ,...eksperimentalna i manipulativna...", smatraju Guba i Linkolnova (Guba \& Lincoln, 1994: 110). Ovo podrazumeva da se istraživanja posmatraju sa stanovišta posmatrača/istraživača a da verifikacija hipoteza ima za cilj njihovu iskustvenu proveru umesto unapređivanja, razvijanja i otkrivanja. Pod uticajem konstruktivističke perspektive u istraživanju sve više se zamenjuju kvantitativni statistički postupci, skreće se pažnja na racionalnost konstrukcija stvarnosti i na diferenciran put izgradnje kognitivnih struktura. Ove se promene tumače kao prelaz iz normativne ka interpretativnoj (konstruktivističkoj) paradigmi. Dolazi do pomeranja od eksperimentalnog pristupa, zasnovanog na objašnjenju, predikciji i kontroli, prema hermeneutičkom, dijalektičkom pristupu koji obuhvata značenje, akciju i interpretaciju (Muratović, 2012). Sam čin istraživanja počinje pitanjima ili brigama učesnika i razvija se kroz dijalektiku, analize i kritike, a koja na kraju vodi do između istraživača i ispitanika stvorene konstrukcije nalaza ili rezultata (Schwandt, 1997).

Kvalitativna istraživanja usmerena su više ka procesu, zanemaruju se precizna statistička merenja i vodi računa o zavisnosti konstrukata realnosti od perspektive posmatrača i metode istraživanja. Takođe se akcenat stavlja na subjektivnu ulogu posmatrača u istraživanju i proceni, interpetaciji nalaza (Gojkov, 2006). Stojnov (2005) navodi da se, u skladu sa ovakvim pristupom razvijaju novi istraživački principi, a pred istraživače se postavljaju novi zahtevi:

○ istraživanja se ne mogu sprovoditi u izolovanim, veštački stvorenim uslovima, već u svakodnevnom životu, konkretnom kontekstu zajedničkog delovanja ljudi;

○ u istraživanjima se mora posvetiti puna pažnja ulozi jezika i diskursa; 
- istraživanja se usmeravaju na osobe i pojedince, umesto na varijable i statistiku;

○ istraživanje i život posmatraju se kao skup dinamičkih interakcija, nešto što je procesualno (Stojnov, 2005: 278; Ševkušić, 2008: 17).

U zavisnosti od referentnih okvira istraživanja uloga istraživača se od ,bespristrasnog naučnika“, odnosno ,donosilaca odluka i tvorca promena” transformiše u ,pasioniranog učesnika“ koji je olakšavalac višeglasne rekonstrukcije” (Heron \& Reason, 1997: 290). Stojnov (2005) ukazuje na neodvojivost nalaza istraživanja prema konstruktivizmu od perspektive saznavaoca i zasnovanosti na ontologiji posmatrača (Stojnov, 2005). S obzirom da je ovde naglasak na relacijama, sam odnos između istraživača i ispitanika ima odlike kreativnog, stvaralačkog procesa kojim se saznavaocu pruža izrazito visok stepen autonomije.

Premda se u pedagogiji i drugim društvenim naukama polazišta konstruktivističke paradigme umnogome razlikuju od tradicionalnog pristupa, što se pre svega ogleda u relativističkoj poziciji, pluralizmu perspektiva, značenja, metoda i vrednosti, insistiranju na dvostrukim značenjima i njihovom uvažavanju kao i alternativnim interpretacijama, nova paradigma istraživačima pruža mnogo slobode, dok istovremeno otvara pitanja i dileme.

\section{Dometi i ograničenja konstruktivizma}

Konstruktivizam je tokom svog razvoja nailazio na brojne kritike, prvenstveno one koje su se odnosile na objektivnost nauke, opasnosti relativizma, širenje postmodernističkih ideja, prelazak sa positivističkih na postpozitivističke filozofije nauke, shvatanje pola i identiteta isključivo kao konstrukcija. Često se navodi da konstruktivisti negiraju postojanje objektivne realnosti, te je važno naglasiti da, pored toga što konstruktivisti realističku poziciju smatraju ograničavajućom, ni u jednom pristupu oni ne poriču stvarnost ili preispituju tvrdnje o postojanju sveta (Chiari, 2017).

Kada je reč o epistemološko-metodološkim dilemama i pitanjima, Tomas Švant (Schwandt, 1998) ističe da se kritike odnose, pre svega, na problem nejasno određenih kriterijuma ili njihovog potpunog odsustva, u smislu naglašenog relativizma. Takođe, u pitanje se dovodi i nedostatak kritičkog oslonca, tačnije da interpretativnim objašnjenjima nedostaje bilo kakvo kritičko interesovanje ili sposobnost za kritiku upravo onih objašnjenja koja proizvode. Čest je i problem autoriteta ili „opasnost od visoko interpretativne nauke i izrazito nezavisan autoritativan stav interpretatora kao opisivača" (Schwandt, 1998: 248). Mnoštvo kritika usmereno je na konstruktivističku sklonost da izvode iz psihološke tvrdnje epistemološki zaključak, odnosno iznošenje epistemoloških tvrdnji. S obzirom da konstruktivisti zastupaju stav da ne postoji neposredni način da se steknu saznanja o svetu oni ne izvode isključivo psihološku tvrdnju, već ujedno i epistemološku, jer se proces konstruisanja dešava u umu. Navedena pitanja i kritike, iako ukazuju na probleme sa kojima se konstruktivizam susreće u svom razvoju, istovremeno omogućavaju perspektivu za tranformisanje i unapređivanje naučnih i istraživačkih okvira. 
Iako postoje dileme koje ukazuju na potrebu za unapređivanjem i redefinisanjem mnogih segmenata u okviru konstruktivističke paradigme, ne može se zanemariti njen uticaj na promene $u$ društvenim naukama. Konstruktivizam je u nauci ukazao na neophodnost rekonstrukcije koncepta saznavanja (Glasersfeld, 1995), isticanjem da ,...ne postoji istina za sve, već samo istina u okviru zajednice..." (Gergen i Gergen, 2006: 63). Za razliku od tradicionalnog shvatanja, gde se znanje vezuje za traganje za istinom, konstruktivisti instistiraju na tome da se znanje sagledava kao proizvod određenih zajednica. Ovakva rekonstrukcija je, smatraju von Glaserfild i Stif (Glasersfeld \& Steffe, 1991), neophodna jer se ne može održati stav da saznajna aktivnost može proizvesti istinitu predstavu objektivnog sveta. Stanovištem o nepostojanju objektivne istine, samim tim, objektivnog znanja, pod uticajem konstruktivističkih ideja došlo je do pomeranja disciplinarnih granica. Dotadašnja shvatanja da se svaka naučna disciplina posmatra putem svog specifičnog objekta proučavanja naišla su na kritiku, da je takav pristup doveo do izolacije među stvaraocima znanja, kako međusobne tako i u odnosu sa širom javnosti. S obzirom da objekte istraživanja konstruišu relevantne zajednice onih koji istovremeno stvaraju i stiču znanje, konstruktivisti insistiraju na labavljenju granica među disciplinama postizanjem dijaloga, među naučnicima i sa okolnim kulturama. Ovo podrazumeva i preispitivanje korisnosti stručnih komunikacija u okviru paradigmi i implikacija van granica naučne zajednice, te je istraživanje koristi i vrednosti značajan doprinos konstruktivista.

Konstruktivistička paradigma u istraživanjima ogleda se u uvažavanju refleksivnosti istraživača i korišćenju višestrukih metoda kako bi se moglo adekvatno odgovoriti na složenost i višesnažnost obrazovnog procesa (Gojkov, 2006). Konstruktivisti smatraju da metode istraživanja oslikavaju pretpostavke i vrednosti vlastite konstruktivnosti (interpretacije, odnosno perspektive posmatranja). Pored isticanja refleksivnosti u procesu istraživanja, ova karakteristika konstruktivizma ogleda se i u pisanim izveštajima. Naime, stilovi pisanja ukorenjeni u ,...tradiciji Istine..." (Gergen i Gergen, 2006: 68), preciznim i nepristrasnim iznošenjem činjenica ne pruža mogućnost autorima da svoje emocije ispolje putem pisanih radova. Ova kritika naročito je važna za oblast društvenih nauka, a time i pedagogije, jer naučni rad ne pruža mogućnost dijaloga sa onima koji su objekti istraživanja. Iz ovog razloga proširivanje oblika izražavanja postaje sve izraženije među autorima i ogleda se u pisanju u prvom licu ili više lica.

Na način na koji je postmodernističko mišljenje uticalo na promene i osnaživanje konstruktivizma u nauci i istraživanjima, promene izazvane globalizacijom ekonomije i komunikacije postavile su pred obrazovanje velike izazove i potrebu za konstruktivistički zasnovanom pedagogijom. U savremenom obrazovanju naglašena je uloga individualnih iskustava u učenju i poučavanju uz uvažavanje konteksta u kojima se ova iskustva stiču (Knežević-Florić i Ninković, 2012). Na temeljima konstruktivističkih ideja razvili su se inovativni kurikulumi i pedagoške strategije, te se umesto paradigme prenošenja znanja intenzivno zastupa paradigma učenja (Milutinović, 2016).

$\mathrm{Na}$ osnovu navedenog, može se zaključiti da je konstruktivizam kao alternativa tradicionalnoj paradigmi izazvala dosta rasprava. Iako bez jasnog struktuiranja i usagla- 
šenosti među samim autorima, ova paradigma unosi korenite promene u sve sfere nauke i naučnog istraživanja. Konstruktivistički potencijal razvoja ideja u okviru ove paradigme nije u usaglašavanju mišljenja ni u jasnim granicama. Gergen i Gergenova (Gergen i Gergen, 2006: 12) ovakav odnos opisuju na sledeći način: „Za konstrukcionistu, naša dela nisu ograničena ničim što je po tradiciji prihvaćeno kao istinito, racionalno ili ispravno. Pred nama se otvara jedan širok spektar mogućnosti, jedan beskrajni poziv na stvaranje novog. Ovo nikako ne znači da treba da odbacimo sve ono što smatramo stvarnim ili dobrim. Ovo samo znači da nismo sputani ni istorijom ni tradicijom".

\section{Zaključak}

Analizom pristupa pojmu paradigma može se zaključiti da se u literaturi ovaj termin upotrebljava dvojako, kao sistem ili konstelacija verovanja i pogleda na svet i kao okvir za istraživanja i razvoj teorije, kojim se istraživači vode kada pristupaju istraživanju. S obzirom da je paradigma određena društveno-kulturnim kontekstom, može se zaključiti da je konstruktivistički pristup karakterističan za postmoderni period pristupa znanju i istraživanju.

Iz perspektive postmodernog mišljenja o konstruktivizmu se govori kao o novoj paradigmi, alternativi dosta drugačijoj od tradicionalnog, pozitivističkog pristupa, u kojoj je naglasak na relativnoj prirodi stvarnosti koja se ko-konstruiše u odnosima među ljudima. Upravo relativistička pozicija koju zauzimaju konstruktivisti često je na meti kritika. S obzirom da u okviru paradigme ne postoji jasan okvir već česta međusobna neslaganja, konstruktivizmu je otežan put do definisanja kriterijuma, uspostavljanja kritičkog oslonca i preciznije epistemologije. Premda nudi mnoštvo različitih, ograničenih i privremenih referentnih okvira za razumevanje stvarnosti, konstruktivistička alternativa zapravo menja način na koji se sagledava slika o svetu. Umesto jedinstvenog puta dolaženja do jedne, apsolutne i objektivne istine, konstruktivizam insistira na mnoštvu puteva i načina dolaženja do saznanja koje se zatim ponovo redefiniše.

U odnosu na oblast vaspitanja i obrazovanja implikacije konstruktivizma od nesumnjivog su značaja. U pedagoškim istraživanjima ukazuje se da, pored otkrivanja zakona iz kojih se izvode pojedinačni slučajevi treba insistirati na razumevanju pojedinačne osobe, grupe i društva. Zastupljenost konstruktivizma u pedagogiji ne podrazumeva negiranje vrednosti i značaja tradicionalne paradigme ili otklon od tradicionalnog pristupa istraživanju već pruža osnovu za proširivanje polja delovanja istraživača u proučavanju pedagoških fenomena.

\section{Literatura}

Anderson, G. L., \& Herr. K. (1999). The New Paradigm Wars: Is There Room for Rigorous Practitioner Knowledge in Schools and Universities?. Educational Researcher, 28 (5), 12-21. 
Babić, N. (2007). Konstruktivizam i pedagogija. Pedagogijska istraživanja, 4 (2), 217 - 229.

BerberovićLj.,iŠošić,B.(2006). Thomas Kuhnievolucijanaučneslikesvijeta. Retrived from https://www.researchgate.net/profile/Bojan_Sosic/publication/301693379_Thomas_Kuhn_i_evolucija_naucne_slike_svijeta/links/5722f89908ae262228a5ff69e/ Thomas-Kuhn-i-evolucija-naucne-slike-svijeta.pdf (7.5.2018.)

Blake, B., \& Pope, T. (2008). Developmental Psychology: Incorporating Piaget's and Vygotsky's Theories in Classrooms. Journal of Cross-Disciplinary Perspectives in Education, 1 (1), 59 - 67.

Brdar, M. (2009). Društveni konstruktivizam i pozitivna epistemologija: o uspostavi naučne činjenice. Sociološki pregled, 18 (4), 445-480.

Bruner, J. S. (1966). Toward a theory of instruction. Cambridge: Belkapp Press.

Bruner, J. S. (1960). The Process of education. Cambridge: Harvard University Press.

Chiari, G. (2017). George A. Kelly and His Personal Construct Theory. Retrived from https:// www.researchgate.net/profile/Gabriele_Chiari2/publication/317064022_George_A Kelly_and_His_Personal_Construct_Theory_iBook/links/5923eceda6fdcc4443fa3cf4/ George-A-Kelly-and-His-Personal-Construct-Theory-iBook.pdf (2.8.2018.)

Denzin, K., \& Lincoln, Y. S. Handbook of qualitative research. Thousand Oaks, CA, US: Sage Publications, Inc.

Djui, Dž. (1966). Vaspitanje i demokratija: Uvod u filozofiju vaspitanja. Cetinje: Obod.

Filstead, W. J. (1979). Using Qualitative Methods in Evaluation Research. Evaluation Review, 5, 259-268.

Freire, P. (2005). Pedagogy of the oppressed. 30th anniversary edition. New York: The Continuum International Publishing Group Inc. Retrived from file://C:/Users/ Marina\%20\%C4\%86iri\%C4\%87/Downloads/FreirePedagogyoftheOppressed.pdf (23.8.2018.)

Gage, N. L. (1989). The Paradigm Wars and Their Aftermath: A "Historical" Sketch of Research on Teaching since 1989. Educational Researcher, 18 (7), 4-10.

Gergen, K. i Gergen, M. (2006). Socijalna konstrukcija ulazak u dijalog. Beograd: Zepter Book World.

Glasersfeld E. von, \& Steffe L. P. (1991). Conceptual models in educational research and practice. Journal of Educational Thought, 25 (2), 91-103.

Glasersfeld, E. von (1995). Radical constructivism: A way of knowing and learning. Washington, DC: Falmer.

Gojkov, G. (2005). Metateorijske koncepcije pedagoške metodologije: Uvod u pedagošku metodologiju. Vršac: Viša škola za obrazovanje vaspitača.

Gojkov, G. (2006). Didaktika i postmoderna - metateorijska polazišta didaktike. Vršac: Viša škola za obrazovanje vaspitača.

Gojkov, G. (2007). Kvalitativna istraživačka paradigma u pedagogiji: prilozi kvalitativnim istraživanjima u pedagogiji. Vršac: Visoka škola strukovnih studija za obrazovanje vaspitača.

Guba, E. G., \& Lincoln, Y. S. (1994). Competing paradigms in qualitative research. In N. K. Denzin \& Y. S. Lincoln (Eds.), Handbook of qualitative research (pp. 105-117). Thousand Oaks, CA, US: Sage Publications, Inc. 
Guba, E. G., \& Lincoln, Y. S. (2005). Paradigmatic Controversies, Contradictions, and Emerging Confluences. In N. K. Denzin \& Y. S. Lincoln (Eds.), The Sage handbook of qualitative research (pp. 191-215). Thousand Oaks, CA, : Sage Publications Ltd.

Heron, J., \& Reason, P. (1997). A Participatory Inquiry Paradigm. Qualitative Inquiry, 3, 274-294.

Johnson, R. B., \& Onwuegbuzie, A. J. (2004). Mixed Methods Research: A Research Paradigm Whose Time Has Come. Educational Researcher, 33 (7), 14-26.

Jukić, R. (2013). Konstruktivizam kao poveznica poučavanja sadržaja prirodoznanstvenih i društvenih predmeta. Pedagogijska istraživanja, 10 (2), 241 - 263.

Knežević-Florić, O., i Ninković, S. (2012). Horizonti istraživanja u obrazovanju. Novi Sad: Filozofski fakultet.

Kont, O. (1989). Kurs pozitivne filozofije. Bački Petrovac: Kultura.

Kuhn, T. S. (1962). The Structure of Scientific Revolutions. Chicago: The University of Chicago Press. Retrived from https://projektintegracija.pravo.hr/_download/repository/Kuhn_Structure_of_Scientific_Revolutions.pdf (12.5.2018.)

Kun, T. S. (1974). Struktura naučnih revolucija. Beograd: Nolit.

Laketa, N., i Vasilijević, D. (2006). Osnove didaktike. Užice: Učiteljski fakultet.

Lutz, S., \& Huitt, W. (2004). Connecting cognitive development and constructivism: Implications from theory for instruction and assessment. Constructivism in the Human Sciences, 9 (1), 67-90.

Mathews, M. (1998). Constructivism in science education. Netherlands: Kluwer.

Maturana H. R., \& Varela F. J. (1992). The tree of knowledge: The biological roots of human understanding. Revised Edition. Boston: Shambhala.

Milutinović, J. (2011). Socijalni konstruktivizam u oblasti obrazovanja i učenja. Zbornik Instituta za pedagoška istraživanja, 43 (2), 177-194.

Milutinović, J. (2016). Socijalni i kritički konstruktivizam u obrazovanju. Novi Sad: Filozofski fakultet.

Muratović, E. (2012). O hermeneutici kao metodi istorije filozofije. Matica, 247-292.

Mužić, V. (1999). Uvod u metodologiju istraživanja odgoja i obrazovanja. Zagreb: Educa.

Nejgel, E. (1974). Struktura nauke. Problemi logike naučnog objašnjenja. Beograd: Nolit.

Niglas, K. (1999). Quantitative and Qualitative Inquiry in Educational Research: Is There A Paradigmatic Difference Between Them? Retrived from http://www.leeds.ac.uk/ educol/documents/00001487.htm (1.8.2018.)

Nikolić, Z., i Carić, M. (2016). Prelamanje paradigmi - Kunova, Poperova, Huserlova i Gadamerova perspektiva. Kultura polisa, 13 (29), 407-420.

Orman, T. F. (2016). "Paradigm" as a Central Concept in Thomas Kuhn's Thought. International Journal of Humanities and Social Science, 6 (10), 47-52.

Palekčić, M. (2010). Herbartova teorija odgojne nastave - izvorna pedagogijska paradigma. Pedagogijska istraživanja, 7 (2), 319 - 340.

Pijaže, Ž. (1968). Psihologija inteligencije. Beograd: Nolit.

Pijaže, Ž. (1983). Poreklo saznanja. Studije iz genetičke epistemiologije. Beograd: Nolit.

Pijaže, Ž. (1994). Uvod u geneticku epistemologiju I - Matematicko misljenje. Novi Sad: Izdavačka knjižarnica Zorana Stojanovića. 
Pijaže, Ž. (1996). Uvod u geneticku epistemologiju II - Fizičko misljenje. Novi Sad: Izdavačka knjižarnica Zorana Stojanovića.

Ponterotto, J. G. (2005). Qualitative research in counseling psychology: A primer on research paradigms and philosophy of science. Journal of Counseling Psychology, 52 (2), 126-136.

Potkonjak, N. (1977). Teorijsko-metodološki problemi pedagogije. Beograd: Prosveta i Institut za pedagoška istraživanja.

Ristić, Ž. (2016). Objedinjavanje kvantitativnih i kvalitativnih istraživanja. Beograd: Evropski centar za mir i razvoj (ECPD), Univerzitet za mir Ujedinjenih nacija.

Roth, W. M., \& Radford, L. (2010). Re/thinking the Zone of Proximal Development (Symmetrically). Mind, Culture, and Activity, 17, 299-307.

Savićević, D. M. (1996). Metodologija istraživanja u vaspitanju i obrazovanju. Vranje: Učiteljski fakultet.

Schwandt, T. A. (1997). Reading the "Problem of Evaluation" in Social Inquiry. Qualitative Inquiry, 3 (1), 4-25.

Schwandt, T. A. (1998). Constructivist, Interpretivist Approaches to Human Inquiry. Retrived from https://www.researchgate.net/publication/232477264_Constructivist_Interpretivist_Approaches_to_Human_Inquiry

Scotland, J. (2012). Exploring the Philosophical Underpinnings of Research: Relating Ontology and Epistemology to the Methodology and Methods of the Scientific, Interpretive, and Critical Research Paradigms. English Language Teaching, 5 (9), 9-16.

Shulman, L. S. (1986). Those Who Understand: Knowledge Growth in Teaching. Educational Researcher, 15 (2), 4-14.

Stojnov, D. (2005). Od psihologije ličnosti ka psihologiji osoba. Beograd: Institut za pedagoška istraživanja.

Ševkušić, S. (2006). Osnovne metodološke pretpostavke kvalitativnih istraživanja. Zbornik Instituta za pedagoška istraživanja, 38 (2), 299-316.

Ševkušić, S. (2011). Kvalitativna istraživanja u pedagogiji. Beograd: Institut za pedagoška istraživanja.

Takaya, K. (2008). Jerome Bruner's Theory of Education: From Early Bruner to Later Bruner. Interchange, 39 (1), 1-19.

Taylor, P., \& Medina, M. (2013). Educational Research Paradigms: From Positivism to Multiparadigmatic. Retrived from https://www.researchgate.net/publication/264196558_Educational_research_paradigms_From_positivism_to_multiparadigmatic (4.3.2018.)

Topolovčan, T., Rajić, V., i Matijević, M. (2017). Konstruktivistička nastava - Teorija $i$ empirijska istraživanja. Preuzeto sa http://milan-matijevic.com/wp-content/ uploads/2010/05/Konstruktivisti\%C4\%8Dka-nastava-predgovor-sa $\%$ C5\%BEetak. pdf (14.7.2018.)

Ültanır, E. (2012). An Epistemological Glance at the Constructivist Approach: Constructivist Learning in Dewey, Piaget, and Montessori. International Journal of Instruction, 5 (2), 195-212.

Vigotski, L. S. (1977). Mišljenje i govor. Beograd: Nolit. 
Wahyuni, D. (2012). The Research Design Maze: Understanding Paradigms, Cases, Methods and Methodologies. Journal of Applied Management Accounting Research, 10 , $1,69-80$.

Willis, J. W. (2007). Foundations of Qualitative Research: Interpretive and Critical Approaches. London: SAGE Publications.

Wilson, B. G. (1997). The postmodern paradigm. In C. Dills \& A. Romoszowski (Eds.), Instructional development paradigms (297-309). Englewood Cliffs NJ: Educational Technology Publications. Retrived from https://www.academia.edu/17481049/The postmodern_paradigm (24.3.2018.)

Yilmaz, K. (2011). Constructivism: Its Theoretical Underpinnings, Variations, and Implications for Classroom Instruction. The Clearing House: A Journal of Educational Strategies, Issues and Ideas, 84 (5), 204-212.

\title{
CONSTRUTIVISM IN PEDAGOGY: CHARACTERI- STICS, STRENGTHS AND LIMITATIONS
}

\author{
Marina Ćirić, Dragana Jovanović \\ University of Nis, Faculty of Philosophy, Department for Pedagogy
}

\begin{abstract}
In this paper we deal with the basic foundations of the constructuvistic paradigm in pedagogy and humanistic sciences. On the basis of analytical approcah to the relevant literature, we point out to the theoreticans who, by their conceptions that people shape reality according to their own needs, interests, prejudice, and cultural traditions, contribute to the establishing of constructivism. Also, we seek out to highlight to the most important contemporary trends of development and representatives of radical, social and developmental constructivism and character of their relation towards to way of presentation and perspective of reality interpretation, knowledge and learning. Whereas the constructivistic development is primarly related to the postmodernistic conception, we are considering constructivism from the aspect of "new paradigm", that is an alternative to the traditional positivistic conceptions. According to the expressed relativistic position, significantly different from traditional paradigm, in this paper we analyzed epistemological and methodological importance of the constructivistic paradigm for educational research, primarly the researches in pedagogy. Developmental perspective is presented by comparison of dominant conceptions from the aspect of criticism and the contribution of constructivism in the field of upbringing and education.
\end{abstract}

Key words: constructivism, paradigm, pedagogy, epistemology, research

\section{Citiranje članka:}

Ćirić, M. i Jovanović, D. (2018). Konstruktivizam u pedagogiji: karakteristike, dometi i ograničenja. Godišnjak za pedagogiju, 3(2), 57-71 
